\title{
USE OF UPSUS TECHNOLOGY AND ITS RELATIONSHIPS WITH THE PRODUCTION AND REVENUE OF RICE FARMERS: A CASE STUDY IN BATANG ASAM DISTRICT OF JAMBI PROVINCE, INDONESIA
}

\author{
Nainggolan Saidin*, Malik Adlaida \\ Department of Agribusiness, Faculty of Agriculture, Jambi University, Indonesia \\ *E-mail: saidinnainggolan@yahoo.com
}

\begin{abstract}
The objective of the study was to measure the use of upsus technology and its relationship with the production and income of paddy rice farmers. Sampling method is done by simple random sampling; sample size is $60 \mathrm{kk}$ farmers. Statistical analysis used is spearman correlation coefficient analysis with t-test. The results showed that the use of upsus technology was in the low to moderate category. Although upsus technology requires significant additional costs but is able to provide additional production, revenue, net income and $\mathrm{RC}$ ratio significantly compared to non-upsus rice farming. The application of upsus technology also provides a benefit-cost ratio that benefits farmers. Application of elements of upsus technology; improved varieties, quality seeds, soil cultivation, planting, fertilizing and irrigation are positively related and very real to production and income (sig. $0.00<a=0,01$ ). While elements of upsus technology, nurseries, pest and disease control, weed control, harvest and post harvest relate positively to production and income but not significantly different (sig. $>a=0,05$ ). If the better the application of elements of technology upsus, it will have a positive and tangible effect on the production and net income of rice farming.
\end{abstract}

\section{KEY WORDS}

Production, revenue-cost ratio, benefit-cost ratio, farmers.

The food crops sub-sector is one part of the agricultural sector and is a producer of strategic commodities in the form of rice that is the staple food of most Indonesians. The need for rice food never recedes, but always increases according to the needs of the population as the factors that most determine the demand for rice. Rice is a food that provides energy in the form of carbohydrates. It is undeniable that rice occupies a very strategic position for the life of the people; on the one hand rice is an economic and social commodity that is the source of farmer's income, and the fulfillment of the need for other society. The existence of rice is difficult to replace and should be available in sufficient quantities.

Various policies outlined by the government in agriculture sector that have been, are, and will be implemented are aimed at promoting agriculture, making farming much more efficient and increasing productivity, higher farmer income levels and more equitable welfare (Suratiyah, 2014).

Increased production of rice farming aims primarily to create rice self-sufficiency and increase farmer income. To achieve this goal the government seeks to increase yield yield per hectare, the policy package outlined is the increased efficiency and effectiveness of the use of upsus technology.

According to Wijaya, I Gede (2016) that the most important input to be considered in the effort to increase productivity of rice farming is by applying rice upsus technology. Rice upsus technology can significantly improve production efficiency and farmer earnings. The use of perfect upsus technology, the production rate will increase from 4.36 tons to 6.82 tons per hectare. Even if applied adaptively, then the level of production can reach 12 tons per hectare.

But in fact, the achievement of increased production is not as expected. Many factors are proposed by various parties that the productivity of lowland rice farming is still low. The low productivity factor per hectare shows that the technical efficiency of using upsus 
technology is still low. This results in no significant difference in production and income levels before, and after the use of upsus technology.

In the relationship above, Wijaya, I Gede (2016) questioned whether it is true that with the recommended technological usage, the production and income of farmers can increase significantly. If the correct use of these technologies can improve the technical and economic efficiency of rice farming, how much power the results? On the use of upsus technology is the amount of additional costs, production, revenues and $\mathrm{RC}$ ratio of rice farming system?

\section{METHODS OF RESEARCH}

Batang Asam District was chosen purposively because this area is the center of rice production in Jambi Province, the sampling method used is simple random sampling method. The sample size is $60 \mathrm{kk}$. The data were collected by interviews guided by a structured questionnaire. To analyze the role of upsus technology in rice farming is by BC ratio (Soekartawi, 2005). Meanwhile, to measure the relation of elements of the use of upsus technology with the production and net income of farmers is done with Spearman correlation coefficient (Djarwanto, 2006):

$$
\mathrm{RS}=\frac{\sum \mathrm{x}^{2}+\sum \mathrm{y}^{2}-\sum \mathrm{d}_{1}^{2}}{2 \sqrt{\sum \mathrm{x}^{2} \cdot \sum \mathrm{y}^{2}}}
$$

Where: $\left.x_{i}^{2}=\left(h_{i}-\bar{h}\right)^{2} ; y_{i}^{2}=\left(k_{i}-\bar{k}\right)\right)^{2} ; d_{1}^{2}=\left(h_{i}-k_{i}\right)^{2} ; X i=$ Score elements of using upsus technology; $\mathrm{Yi}=$ Production or income; hi = Rank score elements use upsus technology; $\mathrm{ki}=$ Rank for production and net income.

Testing is done by $\mathrm{t}$ test with formula:

$$
t=r s \sqrt{\frac{(n-2)}{\left(1-r s^{2}\right)}}
$$

With the rules of decision making: $\mathrm{H}_{\mathrm{O}}$ accepted if: $-\mathrm{t}(\mathrm{a} / 2 ; \mathrm{n}-2) \leq \mathrm{t}$ hit $\leq \mathrm{t}(\mathrm{a} / 2 ; \mathrm{n}-2)$. $\mathrm{H}_{1}$ accepted if: $\mathrm{t}$ hit $>\mathrm{t}(\mathrm{a} / 2 ; \mathrm{n}-2)$ or $\mathrm{t}$ hit < - $\mathrm{t}(\mathrm{a} / 2 ; \mathrm{n}-2)$.

\section{RESULTS AND DISCUSSION}

Level of Use of Upsus Technology by Farmers. The level of application of upsus technology is from the criteria: $000-24.99 \%$ (very low), $25 \%-49.99 \%$ (low), $50 \%-74.99 \%$ (medium), $75 \%-100 \%$ (high). The level of upsus technology is the superior varieties average score of 62.5 or $76.6 \%$ of the recommendation, the average seed quality score of 56.45 or $65.4 \%$ of the recommendations, the average land processing score of 78.2 or 81 , $3 \%$ of recommendation, nursery average score 72,3 or $85,7 \%$ from recommendation, seed average score 58,7 or $55,6 \%$ from recommendation, planting average score 52,6 or $52,2 \%$ of recommendations, average fertilization score of 53.4 or $48.3 \%$ of recommendations, average irrigation score of 62.3 or $54.6 \%$ of recommendations, pest and disease controls average score of 51.7 or $48,5 \%$ of the recommendations, weed controls average score 58.4 or $61.4 \%$ of recommendation, harvest and post harvest average score of 75.6 or $82.5 \%$ of the recommendations. With the level of implementation of intensification (upsus technology) of $63.64 \%$ of the recommendations. This means that on average the level of use of upsus technology is categorized as low to moderate, and this factor may be the cause of the low production of wetland rice farming. Compared with the production potential (12 tons per hectare).

Revenue Analysis and Efficiency of Rice Farming. The amount of net income can be used as an indicator of the profits to be gained by farmers from rice farming. If the net income of farmers is greater, it means that the benefits of farmers get bigger, otherwise if the 
net income of farmers is relatively low, it will be inhibiting factors in an effort to increase production (Tuwo, 2011).

Table 1 it shows that the magnitude of $R / C=2.51$ for non upsus rice which means every sacrifice of production cost equal to Rp. 1.00 will only provide revenue of $R p .2 .51$. While the amount of $R / C$ for rice upsus only amounted to 1.96 , which means $R p .1 .00$ will only provide income for farmers of Rp. 1.96, so if the R / C of the farming can be increased then the flow of economic opportunities obtained by farmers will grow larger, because the magnitude of $\mathrm{R} / \mathrm{C}$ is a determinant factor to increase farmer income. Although upsus technology requires a significant additional cost but able to provide additional production, revenue, net income and $\mathrm{RC}$ ratio significantly compared to non-upsus rice farming.

Role of Using Upsus Technology in Wetland Rice Farming. Using destructive technology to provide additional production is a benefit for farmers, but the use of upsus technology requires additional costs. BENEFIT - cost ratio (B / C) is the big picture (technological feasibility) advantage of using upsus technology.

The role of the use of Upsus technology to B / C can be seen table 2. From table 2 shows that the role of use of upsus technology to additional net income is high with the amount of $B / C=4.50$. This means any additional cost of Rp. 1.00 can bring in additional net income of Rp. 4.50.

Connection of Elements of Use of Upsus Technique with Farmer Net Income Level. The use of upsus technology is an essential element in increasing production efforts. Farm efficiency is highly dependent on the level of use of upsus technology, because upsus technology is an essential factor in increasing productivity per unit farming area (Sutawati, 2014). The relationship of the application of upsus technology with increased production and net income of farmers can be seen in table 3 .

Table 1 - The large current of economic opportunity of paddy upsus and non paddy rice farming

\begin{tabular}{|l|c|c|c|c|}
\hline \multirow{2}{*}{ Description } & \multicolumn{2}{c|}{ Upsus Paddy } & \multicolumn{2}{c|}{ Non Upsus Rice } \\
\cline { 2 - 5 } & Per farmer & Per hectare & Per farmer & Per hectare \\
\hline Production (tonnes) & 4,52 & 5,86 & 3,63 & 4,14 \\
Reception (Rp) & 174.176 .000 & 22.268 .000 & 13.794 .000 & 15.732 .000 \\
Production Costs (Rp) & 7.583 .500 & 8.875 .000 & 6.472 .200 & 7.685 .750 \\
Net Income (Rp) & 9.592 .500 & 13.393 .000 & 7.321 .800 & 8.046 .250 \\
R / C & 2,265 & 2,509 & 2,131 & 1,955 \\
\hline
\end{tabular}

Table 2 - The amount of the benefit-cost ratio upsus use of technology in paddy rice farming

\begin{tabular}{|l|c|c|c|}
\hline \multicolumn{1}{|c|}{ Description } & U PSUs Rice & Non Upsus Paddy & Additional results \\
\hline Production (ton / ha) & 5.86 & 4.14 & 1,72 \\
Receipts (Rp / ha) & 22.268 .000 & 15.732 .000 & $6,536,000$ \\
Production cost (Rp / ha) & $8.875,000$ & $7,685,750$ & 1.189 .250 \\
Opinion of a n bersiah (Rp) & $13,393,000$ & $8,046,250$ & 5.346 .750 \\
BC ratio (B / C) & - & - & 4,496 \\
\hline
\end{tabular}

Table 3 - Relationship of the application of upsus technology with the level of production and net income of farmers from rice farming

\begin{tabular}{|c|c|c|c|c|}
\hline Intensification Score & $\begin{array}{c}\text { Average production } \\
(\text { Ton/Ha) }\end{array}$ & $\begin{array}{c}\text { Total Cost } \\
(\mathrm{Rp} / \mathrm{Ha})\end{array}$ & $\begin{array}{c}\text { Revenue } \\
(\text { USD / ha })\end{array}$ & $\begin{array}{c}\text { Income } \\
(\mathrm{Rp} / \mathrm{Ha})\end{array}$ \\
\hline $450-<480$ & 3.95 & $7,850,600$ & $15,010,000$ & 7159400 \\
$480-<540$ & 4.82 & $7,985,750$ & 18.316 .000 & $10,330,250$ \\
$510-<540$ & 5.42 & 8.382 .255 & $20,596,000$ & $12,213,745$ \\
$540-<570$ & 6.04 & $8,485,240$ & 22952,000 & 14.466 .760 \\
$570-<600$ & 6.68 & $11,530,450$ & $25,384,000$ & $13,853,550$ \\
$600-<630$ & 7.43 & 13.970 .060 & 28.234 .000 & 14.263 .940 \\
\hline
\end{tabular}

From table 3 it can be seen that the higher the score of upsus technology use, the greater the production rate and net income. At a score of $450-480$ the production rate is only up to 3.95 ton / ha with net income of Rp 15,010,000, and at the highest score of $600-630$ gives production rate of 7.43 ton / ha with net income of Rp. 14.263.940, -. 
The magnitude of correlation coefficient elements of upsus technology with production and net income is analyzed by using spearman correlation coefficient. The analysis results can be seen Table 4.

Table 4 - The correlation coefficient upsus technology elements with production and net income

\begin{tabular}{|l|c|c|c|c|}
\hline \multicolumn{1}{|c|}{ Elements of Technology } & Production & Sig & Income & Sig \\
\hline Superior Variety & 0.7521 & 0.0000 & 0.7162 & 0.0000 \\
Quality Seed & 0.6343 & 0.0034 & 0.5966 & 0.0031 \\
Soil Processing & 0.5247 & 0.0043 & 0.4935 & 0.0035 \\
Seedlings & 0.4231 & 0.1426 & 0.4136 & 0.1126 \\
Seeds & 0.4635 & 0.0935 & 0.4035 & 0.0835 \\
Planting & 0.5674 & 0.0042 & 0.5243 & 0.0036 \\
Fertilization & 0.7182 & 0.0000 & 0.6980 & 0.0000 \\
Irrigation & 0.6247 & 0.0031 & 0.5672 & 0.0042 \\
Pest and Disease Control & 0.4215 & 0.1396 & 0.3943 & 0.1256 \\
Weed Control & 0.3542 & 0.2435 & 0.2247 & 0.2334 \\
Harvest and Post harvest & 0.4033 & 0.1573 & 0.3962 & 0.1450 \\
\hline
\end{tabular}

From the amount of correlation coefficient can be seen that elements of upsus technology elements are positively associated with the production and net income of farmers. Superior varieties, quality seeds, soil cultivation, planting, fertilizing, and irrigation are positively related to production and net income of farming (sig $<a=0.01$ ). While the elements of upsus technology, nursery, pest and disease control, weed control, harvest and post harvest are positively related to production and income but not significantly different (sig $>a=0,05)$. This means that all application of upsus technology elements is positively with production and net income of farmers. In other words the better elements of upsus technology applied to rice farming, the more positive and real impact on production and net income. This is in accordance with opinion (Sumaryanto, Wahida, and M. Siregar 2003) stating that the higher the score value of the intensification application, the production of widespread unity of rice farming will increase.

\section{CONCLUSION}

The use of upsus technology is essentially aimed at increasing production and income by increasing production and productivity of wetland rice farming. The rate of use of upsus technology by farmers is still categorized as low to moderate. This is what results in significant differences in production and income levels before and after using upsus technology. If the higher the value of the application of upsus technology then the average level of production and net income of unity will also increase, with the correlation coefficient increasingly positive and significantly different.

To realize the real efficiency improvement of farming, it is necessary to: (1) implementation and improvement of upsus implementation program at the farm level, (2) improvement of infrastructure and upsus program at farmer level.

\section{REFERENCES}

1. Djarwanto, P.S. 2006. Statistik Non Parametrik. Penerbit Liberty. Yogyakarta.

2. Soekartawi. 2005. Prinsip Dasar Ekonomi Pertanian. Penerbit Raja Grafindo Persada.

3. Sumaryanto, Wahida dan M. Siregar. 2003. Determinan Efisiensi Teknis Usahatani Padi di Lahan Sawah Agro Journal Ekonomi; 21 (1):71-96.

4. Suratiyah Ken. 2014. Ilmu Usahatani. Penerbit Penebar Swadaya. Jakarta.

5. Sutawati, Fathimah. 2014. Analisis Efisiensi Teknis dan Alokatif Usahatani Padi Sawah di Kabupaten Sambas, Kalimantan Barat ; Pendekatan Stochastic Frontier.

6. Tuwo, M. Akib. 2011. Ilmu Usahatani, Teori dan Aplikasi Menuju Sukses. Kendari.

7. Wijaya, I Gede M. A Sudewa, 2016. Efektivitas Alokasi Input Usahatani Padi dalam Program Upsus Pajale, Kabupaten Tabanan, Bali. Universitas Udayana, Denpasar. 